\title{
Досвід виконання лапароскопічних операцій у хворих із грижами стравохідного отвору діафрагми та гастроезофагеальною рефлюксною хворобою
}

\author{
Б. О. Матвійчук, А. А. Гураєвський, А. Р. Стасишин \\ Львівський національний медичний університет імені Данила Галицького
}

\section{Experience of performance of laparoscopic operations in patients, suffering hiatal hernias and gastroesophageal reflux disease}

\author{
B. O. Matviychuk, A. A. Hurayevskyy, A. R. Stasyshyn \\ Danylo Galytsky Lviv National Medical University
}

Реферат

Мета. Аналіз результатів хірургічного лікування хворих з грижами стравохідного отвору діафрагми (ГСОД) і гастроезофагельною рефлюксною хворобою (ГЕРХ).

Матеріали і методи. Проаналізовано результати лікування 245 пацієнтів з ГСОД та ГЕРХ, оперованих у клініці хірургії та ендоскопії факультету післядипломної освіти Університету з 2004 по 2018 р. Жінок було 114, чоловіків - 131, середній вік пацієнтів становив $(49 \pm 3,18)$ року, середній індекс маси тіла - 32,9 кг/м².

3 метою діагностики ГСОД та ГЕРХ аналізували скарги хворого, анамнез захворювання, виконували езофагогастродуоденоскопію, рентгеноскопію травного каналу та органів грудної порожнини, проводили добовий рН-моніторинг стравоходу, визначали вміст кальцію у слині. Для стандартизованого опитування та анкетування пацієнтів використовували анкету Лікерта, шкали DeMeester та розраховували індекс якості життя (Gastro Intestinal Quality of Life Index). 3міни у стравоході, викликані рефлюкс-езофагітом, описували відповідно до Лос-Анджелеської класифікації (1994).

Результати. ГСОД діагностовано у 229 (93,5\%) хворих: ковзну - у 203 (88,6\%), параезофагеальну - у 3 (1,3\%), 3мішану у 23 (10,0\%). ГЕРХ виявлено у 93,1\% пацієнтів. У 170 (69,4\%) пацієнтів виконано лапароскопічну фундоплікацію за Ніссеном, у 24 (9,8\%) - фундоплікацію за Тупе, у 51 (20,8\%) - операцію за Ніссеном у власній модифікації (Пат. №59772). Середня тривалість операції становила $(90 \pm 25)$ хв. На етапі опанування методики інтраопераційне ускладнення (ушкодження селезінки з кровотечею) зафіксовано у 3 (1,2\%) пацієнтів. Післяопераційний період ускладнився пневмотораксом у $2(0,8 \%)$ пацієнтів.

Висновки. 3 метою попередження рецидивів захворювання слід враховувати такі фактори ризику, як тип, розмір грижі, виділення та висічення грижового мішка, вибір методу герніопластики та фундоплікації, ожиріння, наявність ускладнень ГЕРХ. Правильний вибір типу операційного лікування та адекватний обсяг операції уможливлюють покращення результатів лікування хворих з ГСОД та ГЕРХ.

Ключові слова: грижа стравохідного отвору діафрагми; гастроезофагеальна рефлюксна хвороба; лапароскопічні операції. Abstract

Objective. Analysis of results of surgical treatment in patients, suffering hiatal hernias (HH) and gastroesophageal reflux disease (GERD).

Materials and methods. Results of treatment were analyzed in 245 patients, suffering HH and GERD, operated on in clinic of surgery and endoscopy of the Faculty of Postgraduate Education University in $2004-2018$ yrs. There were 114 women, men 131 , average age of patients have constituted (49 \pm 3.18 ) yrs, average body mass index $-32.9 \mathrm{~kg} / \mathrm{m}^{2}$.

While doing examination for HH and GERD the patients' symptoms were analyzed, as well as the disease anamnesis, esophagogastroduodenoscopy was performed, roentgenoscopy of the gut and thoracic cavity organs, ambulatory esophageal $\mathrm{pH}-$ monitoring was conducted, the calcium content in saliva was determined. For standardized questioning and interview of patients the Likert questionnaire, DeMeester scale and the Gastro Intestinal Quality of Life Index were calculated. Esophageal changes, caused by refluxesophagitis, were depicted in accordance to Los-Angeles classification (1994).

Results. HH was diagnosed in 229 (93.5\%) patients: axial one - in 203 (88.6\%), paraesophageal - in $3(1.3 \%)$, mixed - in 23 (10.0\%). GERD was revealed in 93.1\% patients. In 170 (69.4\%) patients Nissen laparoscopic fundoplication was performed, in 24 (9.8\%) - Toupet fundoplication, in 51 (20.8\%) - Nissen fundoplication in own modification (Pat. N 59772). The operation duration have constituted $(90 \pm 25)$ min at average. In the learning period for procedure the intraoperative complication (damage of spleen with hemorrhage) was registered in $3(1.2 \%)$ patients. Postoperative period was complicated by pneumothorax in $2(0.8 \%)$ patients.

Conclusion. For prevention of the disease recurrence such risk factors must be taken into account, as the HH type and size, mobilization and excision of hernial sac, selection of hernioplasty and fundoplication method, presence of obesity and the GERD complications. Correct choice of the operative treatment type and adequate volume of the operation makes possible the results of treatment improvement in patients, suffering HH and GERD.

Keywords: hiatal hernia; gastroesophageal reflux disease; laparoscopic operations.

Проблемі грижі стравохідного отвору діафрагми (ГСОД), поєднаній з гастроезофагеальною рефлюксною хворобою (ГЕРХ), присвячено велику кількість публікацій як вітчизняних, так і закордонних [1, 2]. Летальність після відкритих операцій з приводу ГСОД залишається достатньо високою - 25\%. Неспроможність стравохідно- 
шлункового переходу становить 55 - 70\% від загальної кількості ускладнень, а від стравохідно-шлункової кровотечі помирають 22 - 34\% пацієнтів. Великі та гігантські ГСОД, поєднані з ГЕРХ, які діагностують у 50 - 90\% хворих, становлять великий ризик виникнення таких ускладнень, як шлунково-стравохідне виразкування та кровотеча $(2-10 \%)$, метаплазія (5 - 20\%) та аденокарцинома стравоходу (0,5 - 6\%), стриктура (7 - 25\%), перфорація (0 - 4\%), компресія органів середостіння [3 - 5].

Основною причиною виникнення ГСОД, поєднаної з ГЕРХ, $є$ порушення функціонування протирефлюксного бар'єра, до складу якого входить нижній стравохідний сфінктер (НСC) та черевна частина стравоходу, стравохідний отвір діафрагми (СОД), шлунково-діафрагмальна зв'язка, гострий кут Гіса. За тяжкого перебігу ГЕРХ кислотне пошкодження стравоходу призводить до зниження його скоротливості і тонусу НСС, вони не відновлюються після загоєння ерозій під впливом медикаментозного лікування. Ковзну СОД, спричинює розслаблення діафрагмально-стравохідного апарату і збільшення діаметра СОД, внаслідок чого кардіальна частина шлунка зміщується у грудну порожнину крізь СОД. Для змішаної ГСОД, яка трапляється частіше, ніж типова параезофагеальна грижа, характерна загальна слабість френоезофагеальної мембрани в поєднанні з їі локальним розривом, тому не лише стравохідно-шлункове з'єднання ковзає вгору крізь СОД, а й більша чи менша частина шлунка [2].

Ефективність хірургічного лікування хворих з ГСОД та ГЕРХ становить 62 - 97\%, причому в довготерміновій перспективі (строки спостереження понад 5 років) цей показник збільшується до 80 - 96\%. Якість життя достовірно поліпшується після антирефлюксних лапароскопічних операцій за результатами як коротко,- так довготермінових досліджень, включаючи загальні і специфічні огляди [6].

Частота ускладнень після антирефлюксної хірургії залежить від досвіду хірурга, застосовуваної методики, інтенсивності післяопераційного нагляду. Частота переходу до відкритого доступу при лапароскопічній антирефлюксній хірургії коливається в діапазоні 0 - 24\%, проте у більшості досліджень великих клінічних центрів цей показник не перевищує 2,4\% [7].

Специфічними інтраопераційними ускладненнями є перфорація шлунка і стравоходу, пневмоторакс, ушкодження блукаючого нерва. Залежно від методики і досвіду хірурга, частота перфорації шлунка і стравоходу становить 0 - 4\%, хоча окремі автори, повідомляючи про результати лікування 50 пацієнтів, зазначають, що не спостерігали такого ускладнення. Найвищою частота перфораціі (4\%) була при рефундоплікації. Інші автори, що вивчали методики антирефлюксної лапароскопічної хірургії, зокрема торакоскопічної, констатували перфорацію шлунка і стравоходу у 6,7 - 9,1\% хворих. Частота пневмотораксу у більшості проспективних рандомінізованих дослідженнях коливається в діапазоні 0 - 1,5\% [8].

Тривалість операції залежить від застосовуваної методики і становить від 49 до 210 хв. Показник тривалості операції поліпшується, якщо зростає кількість виконаних операцій. Тривалість госпіталізації після лапароскопічної антирефлюксної хірургії становить 1 - 4 дні.
Смертність на 30-й день після операції є рідкісною і зазвичай нульовою. Гнійно-септичні ускладнення включають ранові інфекції (частота виникнення коливається в діапазоні 0,2 - 3,1\%) і післяопераційні грижі (частота виникнення коливається в діапазоні 0,17 - 9\%). Частота виконання повторних хірургічних втручань залежить від методики, показань, тривалості спостереження і коливається в діапазоні 0 - 15\% [9].

Мета дослідження: аналіз результатів хірургічного лікування хворих з ГСОД і ГЕРХ.

\section{Матеріали і методи дослідження}

Проаналізовано результати лікування 245 пацієнтів 3 ГСОД та ГЕРХ, оперованих у клініці хірургії та ендоскопії факультету післядипломної освіти Університету з 2004 по 2018 р. Жінок було 114, чоловіків - 131, середній вік пацієнтів становив $(49 \pm 3,18)$ року, середній індекс маси тіла $-32,9$ кг $/ \mathrm{M}^{2}$.

3 метою діагностики ГСОД та ГЕРХ аналізували скарги хворого, анамнез захворювання, виконували езофагогастродуоденоскопію, рентгеноскопію травного каналу та огранів грудної порожнини, проводили добовий $\mathrm{pH}-\mathrm{MO}-$ ніторинг стравоходу, визначали вміст кальцію у слині. Для стандартизованого опитування та анкетування пацієнтів застосовували анкету Лікерта, шкали DeMeester та розраховували індекс якості життя (Gastro Intestinal Quality of Life Index). Зміни у стравоході, викликані рефлюкс-езофагітом, описували відповідно до Лос-Анджелеської класифікації (1994).

Отриманий матеріал опрацьовували статистично з використанням комп'ютерної програми Excel. Вірогідними вважали відмінності, коли рівень значущості (р) був менше 0,05 [10].

\section{Результати}

ГСОД діагностували у 229 (93,5\%) хворих: ковзну - у 203 (88,6\%), параезофагеальну - у 3 (1,3\%), змішану - у 23 (10,0\%). ГЕРХ виявили у 93,1\% оперованих пацієнтів.

Враховуючи рекомендації консенсусу Товариства американських абдомінальних і ендоскопічних хірургів (SAGES) $[1,3]$, ми виконували такі етапи операції: розкриття діафрагмально-стравохідної зв'язки справа наліво; виділення та збереження гілок (печінкова, передня, задня) блукаючого нерва; виділення обох ніжок діафрагми; мобілізація не менше 3 см черевної частини стравоходу через його отвір у діафрагмі; пересічення коротких судин дна шлунка; задня крурорафія швами, що не розсмоктуються; створення антирефлюксної манжети розміром 1,5 - 2 см, причому найбільш дистальний шов включав передню м'язову стінку стравоходу; встановлення калібрувального зонда в момент формування манжети. Описана послідовність етапів операції забезпечила хороший післяопераційний прогноз, зокрема, частота післяопераційних ускладнень становила 2,04\%, середня тривалість перебування пацієнтів у лікарні після операції - $(3 \pm 4,57)$ дня.

У 170 (69,4\%) пацієнтів виконали відеолапароскопічну фундоплікацію за Ніссеном, у 24 (9,8\%) - фундоплікацію за Тупе, у 51 (20,8\%) - операцію за Ніссеном у власній модифікації (Пат. №59772). Середня тривалість операції ста- 
новила (90 \pm 25$)$ хв. На етапі опанування методики інтраопераційне ускладнення (ушкодження селезінки з кровотечею) констатували у 3 (1,2\%) пацієнтів. Післяопераційний період ускладнився пневмотораксом у 2 (0,8\%) пацієнтів. Рецидив ГСОД і ГЕРХ виник у 3 (1,2\%) пацієнтів через 12 , 18 та 36 міс після операції, які були первинно оперовані з приводу гігантських змішаних ГСОД та «короткого стравоходу». У жодного пацієнта не виникли перфорація стравоходу і шлунка, міграція антирефлюксної манжети, післяопераційні гнійно-септичні чи тромбоемболічні ускладнення. Через 3 міс у 4 (1,6\%) оперованих хворих виявлено помірну дисфагію, консервативне лікування якої мало добрі результати, через 12 та 36 міс у хворих скарг не було. Відмінний індекс якості життя зафіксували у 93,0\%, добрий - у 7,0\% опитаних пацієнтів.

\section{Обговорення}

Проаналізувавши власний досвід і рекомендації SAGES щодо хірургічного лікування ГСОД, ми схильні вважати, що рутинна реконструкція повністю безсимптомних параезофагеальних гриж не показана [11], тобто у разі таких гриж можлива безпечна вичікувальна тактика. У висновку, що грунтується на аналізі 5 рандомінізованих досліджень [1], стверджується, що операцію варто виконувати лише за наявності обструкції виходу із шлунка, тяжкого шлунково-стравохідного рефлюксу з анемією, а також у хворих із защемленням шлунка. За результатами рандомізованих контрольованих досліджень, простеженими в короткі строки, автори рекомендують використання підсиленої пластики СОД, хоча це і не підтверджено довгостроковими результатами. Частота тяжких ускладнень (рубцеві стриктури, арозивна кровотеча) через застосування сіток коливається від 1,5 до 20\% [12].

Виконуючи операцію з приводу параезофагеальних та змішаних ГСОД, грижовий мішок слід виділяти від структур середостіння, а потім відсікати. Вважаємо, що виділення грижового мішка під час такого втручання вивільняє обмежений стравохід, полегшує інтраопераційне вправлення грижі, знижує ймовірність виникнення ранніх рецидивів, а також захищає стравохід від ятрогенного пошкодження.

Фундоплікація необхідна при ГСОД з метою попередження шлунково-стравохідного рефлюксу та виникнення рецидиву в післяопераційному періоді. Повторні лапароскопічні операції можуть успішно виконувати досвідчені хірурги. Реконструкція рецидивних ГСОД показана, коли симптоматика відповідає анатомічним змінам. Хірургічну ревізію часто можна завершити лапароскопічно за наявності адекватних навиків.

\section{Висновки}

1. Серед ускладнень після антирефлюксних операцій найбільш значущими є рецидив ГСОД, ГЕРХ, дисфагія, gas-bloat синдром.

2. 3 метою попередження рецидивів захворювання слід враховувати такі фактори ризику, як тип, розмір грижі, виділення та висічення грижового мішка, вибір методу герніопластики та фундоплікації, ожиріння, наявність ускладнень ГЕРХ.

3. Правильний вибір типу оперативного лікування та адекватний обсяг операції уможливлюють покращення результатів лікування хворих з ГСОД, поєднаними з ГЕРХ.

\section{References}

1. Kohn GP, Price RR, DeMeester SR, Zehetner J, Muensterer OJ. The guidelines for the management of hiatal hernia. Practice/Clinical Guidelines published by the Society of American Gastrointestinal and Endoscopic Surgeons. Surgical endoscopy. 2013;27(12):4409-28. doi: 10.1007/s00464-013-3173-3.

2. Huberhryts NB, Lukashnvych HM, Holubova OA. Hryzhy pyshchevodnoho otverstvyya dyafrahmy: sovremennye predstavlenyya o patoheneze y lechenyy Suchasna hastroenterolohiya. 2012; 3(65):105-13. [In Ukrainian].

3. Stefanidis D, Hope WW, Kohn GP. Guidelines for surgical treatment of gastroesophageal reflux disease. Surg Endosc. 2010;24(11):2647-69. doi:10.1007/s00464-010-1267-8.

4. Reva VB. Topohrafo-anatomichne obgruntuvannya plastyky diafrahmy z pryvodu diafrahmal'nykh hryzh. Klin anat ta oper khirurhiya. 2003;2(1):41-5. [In Ukrainian].

5. Tovkach YuV. Suchasni tekhnolohiyi v khirurhichnomu likuvanni gastroesophageal'noyi reflyuksnoyi khvoroby Klinichna ta eksperymental'na patolohiya. 2013;1(43):194-6 [In Ukrainian].

6. Rosenthal R, Peterli R, Guenin MO, von Flue M, Ackermann C. Laparoscopic antireflux surgery: long-term outcomes and quality of life. J Laparoendosc Adv Surg Tech A. 2006;16:557-61. doi:10.1111/j.16006143.2011.03984.x.

7. Anvari M, Allen C, Marshall J, Armstrong D, Goeree R, Ungar W, Goldsmith C. A randomized controlled trial of laparoscopic nissen fundoplication versus proton pump inhibitors for treatment of patients with chronic gastroesophageal reflux disease: One-year follow-up. Surg Innov. 2006;13:238-49. doi:10.1177/1553350606296389.

8. Champion JK. Thoracoscopic Belsey fundoplication with 5-year outcomes. Surg Endosc. 2003;17:1212-5. doi:10.1007/s00464-010-1267-8.

9. Zacharoulis D, O’Boyle CJ, Sedman PC, Brough WA, Royston CM. Laparoscopic fundoplication: a 10-year learning curve. Surg Endosc. 2006; 20:1662-70. doi:10.1007/s00464-010-1104-0.

10. Lapach SN, Chubenko AV, Babich PN. Statistical methods in medical - biological studies using Excel. Kyiv: «Morion»; 2000. 315 s. [In Ukrainian].

11. Stylopoulos N, Gazelle GS, Rattner DW. Paraesophageal hernias: operation or observation? Ann Surg. 2002;236:492-500; discussion 500491. doi: 10.1007/s00464-013-3173-3.

12. Stadlhuber RJ, Sherif AEl, Mittal SK, Fitzgibbons RJ. Mesh complications after prosthetic reinforcement of hiatal closure: a 28-case series. Surgical endoscopy. 2009;23(6):1219-26. doi:10.1007/s00464008-0205-5. 